CORRECTION

\title{
Correction to: No difference in survival after HLA mismatched versus HLA matched allogeneic stem cell transplantation in Ewing sarcoma patients with advanced disease
}

U. Thiel (D), S. J. Schober (ID, A. Ranft, H. Gassmann, S. Jabar, K. Gall, I. von Lüttichau, A. Wawer, E. Koscielniak, M. A. Diaz, M. Ussowicz (D, I. Kazantsev (D) B. Afanasyev, M. Merker, T. Klingebiel (D), A. Prete, B. Gruhn (D), P. Bader, H. Jürgens, U. Dirksen (D), R. Handgretinger, S. Burdach and P. Lang

(c) The Author(s) 2021

Bone Marrow Transplantation (2021) 56:2320; https://doi.org/10.1038/s41409-021-01421-8

Correction to: Bone Marrow Transplantation (2021) 56:1550-1557; https://doi.org/10.1038/s41409-020-01200-x, published online 29 January 2021

Due to a processing error, the shared first authorship between Sebastian Schober and Uwe Thiel nor the shared last authorship between Stefan Burdach and Peter Lang was not taken.

The original article has been corrected.

\begin{abstract}
(c) (i) Open Access This article is licensed under a Creative Commons Attribution 4.0 International License, which permits use, sharing, adaptation, distribution and reproduction in any medium or format, as long as you give appropriate credit to the original author(s) and the source, provide a link to the Creative Commons license, and indicate if changes were made. The images or other third party material in this article are included in the article's Creative Commons license, unless indicated otherwise in a credit line to the material. If material is not included in the article's Creative Commons license and your intended use is not permitted by statutory regulation or exceeds the permitted use, you will need to obtain permission directly from the copyright holder. To view a copy of this license, visit http://creativecommons. org/licenses/by/4.0/.
\end{abstract}

(c) The Author(s) 2021 